\title{
The Shifting Epistemological Foundations of Cholera Control in Japan (1822-1900)
}

Les fondations épistémologiques mouvantes du contrôle du choléra au Japon

(1822-1900)

1822 から 1900 年間日本に於けるコレラ抑制の变動する認識論的基礎

William Johnston

\section{(2) OpenEdition}

Journals

Electronic version

URL: http://journals.openedition.org/extremeorient/339

DOI: $10.4000 /$ extremeorient.339

ISSN: 2108-7105

Publisher

Presses universitaires de Vincennes

\section{Printed version}

Date of publication: 1 September 2014

Number of pages: 171-196

ISBN: 978-2-84292-411-9

ISSN: 0754-5010

Electronic reference

William Johnston, «The Shifting Epistemological Foundations of Cholera Control in Japan

(1822-1900) ", Extrême-Orient Extrême-Occident [Online], 37 | 2014, Online since 01 September 2017, connection on 21 April 2019. URL : http://journals.openedition.org/extremeorient/339 ; DOI : 10.4000/ extremeorient.339 


\title{
The Shifting Epistemological Foundations of Cholera Control in Japan (1822-1900)
}

\author{
William Johnston
}

\section{Introduction}

Although generally not discussed in these terms, modern Japan's first foreign occupation occurred during the nineteenth century. The initial invasion occurred in 1822, long before the arrival of Commodore Perry in 1853, not to mention General Mac Arthur's army nearly a century later. While this first invasion did not result in a long-term occupation, its second invasion in 1858 most likely did, with calamitous consequences for the Japanese people.

This occupation is not thought of in these terms because the invader was an invisible intruder, Vibrio cholerae, the bacillus that causes cholera. More specifically, it was Vibrio cholerae of the serogroup O1, of what has become known as the classical (as opposed to the El Tor) biotype, although it is not clear whether it was of the Inaba or Ogawa serotype. ${ }^{1}$ While for some it might seem surprising to consider a bacillus as a historical actor with this level of agency, there is no denying that, in the words of Bruno Latour, it "does modify a state of affairs by making a difference." 2 The cholera bacillus made a difference both in people's lives and in the practices and institutions of medicine and public health. ${ }^{3}$ Although exact statistics do not exist, especially for the 1822 epidemic or for the years between 1858 and 1876, according to the official figures, between 1877 and 1900, cholera killed over 530,000 persons. The disease also caused inestimable social and economic disruption.

How people in Japan - physicians and laypersons alike- understood this invader reflects changing approaches to understanding both the natural and human worlds. Those changes were in part the result of increasing contact

1. Colwell 1996: 2025-2031; Colwell 2004: 285-289.

2. Latour 2005: 71; see also Sayes 2013: 1-16.

3. Chemouilli 2004a; Chemouilli 2004b; Chemouilli 2004c. 
with Western ideas about cholera and its control. Yet it is also important to remember that even in Europe those ideas were often conflicting and undergoing rapid changes during the last half of the nineteenth century. The changing understandings of cholera in Japan were also in part the result of changing conceptions and infrastructures of public health in which the modern state took on a larger role in the health of the Japanese people as its leaders imagined necessary for the health of the state itself. Where the health of the people was physical and dealt with bodies one could see, the health of the state was conceptual and dealt with an imagined body, although one whose reality few questioned. Finally, and perhaps most importantly, understandings of cholera depended on how the Japanese saw themselves in reference to the rest of East Asia and the world. Cholera itself had a political significance that played out in these understandings, as contemporary descriptions of the disease show.

The goal of this essay is to trace how the dominant understandings of cholera changed during the nineteenth century, and how a confluence of multiple understandings of cholera facilitated the establishment of public health institutions aimed at controlling this disease. Only during the last decade of the nineteenth century did a single, bacteriological explanation of cholera's etiology begin to dominate the discourses of medicine and public health in Japan, yet this did not prevent the creation of an integrated state apparatus for the control of the disease during the 1870s and 1880s. This was possible because in nineteenth century Japan, as in nineteenth century France as shown by Bruno Latour in The Pasteurization of France, there existed an infrastructure of hygiene that predated the rise of bacteriology as a foundation for the institutions of public health. ${ }^{4}$ In Japan, the idea of hygiene (eisei) was transplanted onto the idea of "nourishing life" ( $y \bar{o} j \bar{o}$, also translated as "regimen"), which had developed a large and sophisticated body of literature by the end of the eighteenth century. ${ }^{5}$ In short, the rise of bacteriology was not necessary for the creation of state-directed cholera control measures in nineteenth century Japan, but rather was only one additional element in the contemporary epistemological transformation of cholera. The state apparatus emerged from a confluence of indigenous ideas about health and well being with Western ideas of hygiene to which bacteriology was a relative late comer.

An assumption at the foundation of this essay is that when nineteenth century Japanese documents refer to cholera, beginning in 1822 and continuing thereafter, it is the same disease that medicine today calls by the same name.

4. Latour 1988: 16-26.

5. Takizawa 2011: 7-12; Andoh 2003; Chemouilli 2004c: 181-183. 
When cholera first appeared in Japan in 1822 it displayed symptoms and a prognosis unlike anything previously known. Its name spawned a new Japanese word-korori- that punned on the Western term. The full name was mikka korori, or "three-day collapse," that reflected the rapid progression of the disease from first symptoms to death; in a variant, the disease also was called mikka tonkoro, which meant the same thing. ${ }^{6}$ Unlike many other diseases such as syphilis and tuberculosis, cholera's distinct signs and symptoms make it possible to trace the history of this malady from its initial pandemic in 1817 to contemporary times. We can, nonetheless, assume the existence of a gap between cholera as an ontological entity understood through biology, pathology, and related sciences today, and the epistemological frameworks of the past. Once we assume that Vibrio cholerae as we understand it today was essentially the same organism that first invaded Japan in 1822 and occupied it later in the nineteenth century, we can also assume that its behavior then was close to what it is now. This is, of course, an arbitrary assumption in that what modern medicine accepts as cholera's ontological reality is based on later epistemological foundations: we don't know for certain much about the bacillus that existed during the nineteenth century. This might change in the near future, as archaeologists have discovered a mass grave in Italy that contains bodies of what they believe to be cholera victims, and they are in the process of analyzing DNA samples for what they suspect is the cholera bacillus. ${ }^{7}$ Nevertheless, during the past twenty years we have learned much about Vibrio cholerae and the disease it causes, while the organism continues with its own development as determined by its biological properties and the ecologies in which it finds itself.

By accepting the fact that our knowledge of cholera continues to evolve, we can avoid the idea that bacteriology introduced the first "accurate" knowledge of this organism. Rather it is possible to measure the degree of overlap between pre-bacteriological thought and how we understand the disease today without assuming that the adoption of Western "scientific" thought was intrinsically superior to previous understandings of this disease. During most of the nineteenth century medical scientists in Europe, the United States, and Japan embraced conflicting understandings of cholera while competing for ascendency. The story that emerges hardly follows a linear progression. By no means is it the goal of this paper to show how earlier epistemologies inevitably developed into today's scientific knowledge. It is, rather, to show how changing understandings of cholera manifested palimpsests that evidenced traces of

6. Matsumoto 1980: 15.

7. Gibbons 2013: 1310 . 
earlier knowledge, while at the same time to demonstrate how the questions and problems of one period often disappeared into irrelevancy rather than being answered in the next. Epistemological change in the science of cholera occurred not simply due to the diligence of scientists but also due to the forces of politics, economics, and religion. It came about through what Latour called "translations, drifts, and diversions." 8 The following discussion examines some of the most significant of those translations, drifts, and diversions so that the forms and textures of the Japanese historical transformation that occurs with cholera's occupation of the country become apparent.

\section{A new disease: 1822}

Perhaps the single greatest mystery in the history of cholera is why it initially spread around the world when it did. The first wave out of India arose in 1817 . Before that, there were reports of a disease whose symptoms seem to be those of cholera as we know it today. Premodern Indian texts contain references to a violent enteric disease that suggest cholera. As far back as the time of Vasco da Gama (1460-1524), European travelers described a disease that might have been cholera. And in the eighteenth century, British seamen reported a disease with cholera-like symptoms. ${ }^{9}$ However if the disease we know today - and more specifically the Vibrio cholerae strain that causes itexisted before 1817 it is unclear why it did not spread beyond the Bay of Bengal before then. Technology does not seem to be the reason: travel to Asia did not suddenly become easier at this time, as steamships did not traverse ocean routes to India until the $1850 \mathrm{~s} .{ }^{10}$

One possibility is that a biological change in the cholera bacillus occurred at this time. Vibrio cholerae itself is a common bacillus that appears worldwide. However the form of the bacillus that causes cholera as we know it requires co-infection with two separate viruses, known as bacteriophages, in order to become pathogenic. It is possible that new forms of bacteriophages or other genetic material changed the structure of Vibrio cholerae in a way that allowed it to travel more widely than before. ${ }^{11}$ In any event, from 1817 , pathogenic Vibrio cholerae set out on what became a global colonization project. It came to reside in estuaries and other waterways from which it caused outbreaks of

8. Latour 1988: 11.

9. Colwell 1996: 2025.

10. MacPherson 1998: 492-494.

11. Faruque and Mekalanos 2012: 1-10. 
disease across the world. This was possible because the bacillus remains viable not only in the ecology of the human body but also in a range of creatures ranging from plankton to fish and birds. It did not, in other words, require constant transmission among humans in order to inhabit a local environment. In the last decades of the twentieth century cholera had become widely endemic, by which time the idea of cholera pandemics, which made sense during the nineteenth century, was no longer useful. ${ }^{12}$

When cholera did finally emerge beyond the Bay of Bengal from 1817, the first pandemic did not reach Europe. It spread across South and Southeast Asia, reaching Batavia by 1820 . Contemporary Japanese sources note that Jan Cock Blomhoff (1779-1853), who became the Director (opperhoffd) of the Dutch mission on Dejima in Nagasaki harbor from 1817, gave the Japanese their first descriptions of cholera as it had struck Jakarta. ${ }^{13}$ In 1822 the disease reached Nagasaki and then proceeded to the Hiroshima area, the island of Shikoku, and as far as Osaka and Kyoto. It stayed primarily along the seacoast and rivers and was reported going east toward Edo (present-day Tokyo) but began to recede before arriving there. Between the eighth and tenth months of 1822 cholera killed several thousand but then disappeared from Japan for 36 years. ${ }^{14}$

Nevertheless, the disease clearly made its mark. Contemporary observers noted that it was similar to a disease known in Japan at the time as kakuran. ${ }^{15}$ As a disease category, kakuran (Chinese, huoluan) was based on Chinese medical thought that dated to ancient times. ${ }^{16}$ By the eighteenth century, the Chinese revival of ancient medical thought, and in particular of the Shōkanron (Ch. Shanghan lun) and its elaboration by Zhang Zhongjing had become highly influential among Japanese physicians. ${ }^{17}$ Kakuran was a prominent disease category for practitioners of this school, which remained influential in Japan into the $1860 \mathrm{~s} .{ }^{18}$ Although scholars have debated whether cholera as we know it today was introduced to China before it arrived there in 1820 during the first pandemic, it seems likely that kakuran was analogous to what people in the contemporary West called mordisheen, mort-de-chien, or cholera morbus. ${ }^{19}$ All of these had symptoms of diarrhea, nausea, fever, and debilitation and

12. Johnston 2012: 35 .

13. Bunsei jingo aki tenkō byō koreri morubusu keiken n. d.: n. p; Yamamoto 1982: 3-5.

14. Matsuura 1859: n. p.

15. Matsuura 1859: n. p.; Hirahara 1842: n. p.

16. MacPherson 1998: 496-497.

17. Elman 2008: 108.

18. Odai 1864.

19. MacPherson 1998: 495-503. 
could cause death. Food poisoning was frequently the cause, which, as we know now, would have been common due to a lack of refrigeration and the use of night-soil as fertilizer. Nineteenth-century medical texts do associate kakuran with the contamination of food and drink, but also consider heat and cold and an individual's personal physique to be key causes of this malady. ${ }^{20}$ In addition, it is important to keep in mind that disease categories at the time were often vague - just as they were in European and North American medicineand diagnosis depended on a physician's intellectual allegiances. At least until the 1870s, Japanese physicians whose practices were based primarily on Chinese ideas tended to diagnose kakuran whereas those who were influenced by European medicine tended to diagnose korera (or korori). ${ }^{21}$

While, in historical perspective, this was cholera's first incursion into Japan, at least one contemporary observer, Hirahira Yūteki, a physician to the lord of Aki domain in modern-day Hiroshima prefecture, believed it had appeared in the previous century. ${ }^{22}$ In 1842 , Hirahira wrote a work called Korori ben (Treatise on cholera) in which he noted his observations from 1822: "I have observed many maladies, including influenza, mordisheen (kakuran), smallpox, infections, and they all were different from this disease. Although various treatments were attempted none were effective.... Commonly, this was called korori." 23

While in this way Hirahara asserted that this disease was unlike any he had seen himself, he also claimed that the disease had previously appeared in Japan. He wrote that 50 or 60 years earlier, which would have been in the 1780s or 1790s, people had seen this disease; he cited the Honzô kômoku (Chinese materia medica; Bencao gangmu in Chinese). There is no entry for korori in this work; there is one, however, for kakuran, which implies that Hirahara was equating korori with kakuran-something he does explicitly in a later passage of the Korori ben. ${ }^{24}$ Hirahara was, in effect, looking for ways to translate unusual phenomena into a language common to himself and his contemporaries. His struggle was self-conscious. He wrote:

It is possible that biased views and deluded theories can arise. One should not be mistaken this way. The section of this work that contains the description of mordisheen (kakuran) specifies that it includes vomiting and diarrhea, and hence

20. Odai 1864: 8a, 9b-10a; Matsuura 1859: n.p.

21. Matsuura 1859; Odai 1864; Shingū 1858.

22. Hirahara 1842: n. p.

23. Hirahara 1842: n. p.

24. Taki 1918: 173-174. 
this name is used. This illness also includes the occurrence of fever, headache, lethargy, and chills, in addition to nausea and diarrhea. Together, these are called kakuran. Furthermore, the main section of this work calls for an examination of the pulse, and based [on the fact that both diseases show] similar symptoms, what we know as korori is thus kakuran. This [disease] is kakuran. Confucius says, "If names be not correct, language is not in accordance with the truth of things. If language be not in accordance with the truth of things, affairs cannot be carried on to success." ${ }^{25}$ If I have made these claims without properly keeping names in order, then I fear that [therapy and prevention] will not be successful. ${ }^{26}$

For Hirahara, the correct understanding of disease depended on the correct clinical understanding of its signs and symptoms. He looked for a familiar framework in order to grasp symptoms that were familiar yet unique. In addition to describing the symptoms of kakuran, he also included fever, the cessation of urination, cramps in the limbs, which also then became extremely cold, and delirium. Finally, he specified that there was no successful treatment for this disease, and presented a series of case histories in which only two out of eleven patients, whose ages ranged from 2 to 60 , recovered. ${ }^{27}$

Other contemporary accounts of the 1822 epidemic described similar symptoms, adding cyanosis, sunken eyes, and abdominal pain. They also noted that death could occur on the first day of symptoms but often occurred on the second or third day. ${ }^{28}$ Most recommended treatments form this time included opium, a recommendation that continued throughout the century. Prevention was limited to moderation in food and drink-the foundations of $y \bar{o} j \bar{o}$ discourse ${ }^{29}$ It is also significant that accounts of this early epidemic clearly depicted it as coming from abroad. For example one contemporary observer, a physician named Sasaki Chūsetsu, after describing a conversation with a Dutch visitor to Edo in which he learned that cholera had reached Batavia two years earlier, in 1820, then wrote, "A kind of pernicious essence (reiki) has spread between heaven and earth, and has reached our country." 30

While this first incursion by the cholera bacillus was short, having lasted only two to three months, it left its mark on Japanese medical discourse and language. As previously noted, a common word for cholera, korori, was

25. Translation by Legge 1971: 263-264.

26. Hirahara 1842 .

27. Hirahara 1842: n. p.

28. Bunsei jingo aki tenkō byō koreri morubusu keiken n. d.: n. p.; Matsuura 1859: n. p.

29. Bunsei jingo aki tenkō byō koreri morubusu keiken n. d.: n. p.

30. Sasaki n. d.: n.p. 
a play on both the Western term for the disease-transliterated as korera in Japanese - and on the rapid course it often took. Hirahira's text, while otherwise assuming a scholarly tone, included two lines of doggerel that revealed popular perceptions of the disease. One read: Korori to kokete sora ibiki, which translates roughly as, "Tumbling down and falling over, pretending to snore." Sora ibiki or "pretending to snore" possibly referred to the death rattle. The other read: Yomego no hirune mo korori to se, or "Like a new bride taking a nap, tumbling right over." This is as much a comment on relations between brides and their mothers-in-law as on the disease, in that brides had so many responsibilities that they hardly slept at night and as a consequence could fall asleep almost instantly during the day. Another explanation for the term korori was that a person with the disease could fall over dead three days after getting it, resulting in the name mikka korori or "the three-day collapse." ${ }^{31}$ From the time of this first epidemic, the word for cholera in Japanese was written with Chinese characters that on the one hand could be read phonetically as korori while often, if not always, reading them as korera through the use of furigana (phonetic pronunciation guides). Although most of Hirahira's text focuses on symptoms, diagnosis, and treatment, he does note that the disease was widespread. He wrote: "It was common among travelers and at inns, and destroyed households, leaving them unguarded." ${ }^{32}$ While it is clear that this first epidemic of cholera had a powerful impact, a sense that the disease imperiled the entire country does not seem to have occurred. That would change with the second cholera epidemic to reach Japan.

\section{Cholera's second wave, 1858}

Japan's first invasion by the cholera bacillus in 1822 was short, generally localized, and caused relatively few deaths. The second invasion came in 1858 , persisted for months into 1859, was extended, widespread, and caused deaths that possibly numbered over a hundred-thousand. ${ }^{33}$ The American ship U.S.S. Mississippi, which docked in Nagasaki in the sixth month of 1858, had sailors with the disease who were the source of its introduction. From there, cholera spread east and reached Edo the following month. According to one count, over a quarter-million residents of the city died from cholera during the next

31. Nakajima 1982: 46.

32. Hirahara 1842: n.p.

33. Yamamoto 1982: 8-25; Gramlich-Oka 2009: 32-73. 
two months. ${ }^{34}$ Even if these numbers were exaggerated the toll was enormous. By the end of the year cholera had spread throughout most of the main islands of Japan. Whereas the first cholera epidemic resulted in only a handful of texts about the disease, this second epidemic elicited a large number of works, most by and for medical specialists, but also some written for a general audience by authors of popular literature, both fictional and non-fictional. Both kinds of works receive attention in the following discussion.

By 1858, a great deal of medical discourse in Japan had become part of a larger discourse that tied it together with much of Europe and North America. Japanese physicians had begun to translate various Western medical texts from the 1770s. By 1853, when Americans used warships to persuade the Japanese government to allow foreign ships into several ports and not just into Nagasaki, many Japanese physicians were gaining a familiarity with various Western medical ideas. ${ }^{35}$ As a consequence, when this foreign disease once again entered the country, Japanese physicians reached to foreign texts to help understand and treat it.

One such approach was exemplified by the work of a Kyoto physician named Shingu Ryōkaku. He wrote that on the 24th day of the 8th month of 1858, his older brother came to him and said that based on the way the disease was spreading, cholera (korori byô) would soon be upon them but they lacked any effective treatment for it. ${ }^{36}$ His father told him that the disease had appeared in Japan over 30 years earlier, when it was called mikka korori (three-day collapse), but that because it had remained for only a short time it had been impossible to establish its cause or find a cure. He also said that although practitioners who used Chinese medical theories had described similar diseases, they were not clear regarding causes or treatments. As a consequence, Shingū and another physician, Ōmura Ten, decided to translate a Dutch text written by a German physician, Georg Friedrich Most (1794-1832), and make it available to other physicians as quickly as possible. According to the translators, Most had contracted cholera and written his work largely based on personal experience. ${ }^{37}$ They began their translation on the 25th day of the 8th month of 1858 , and finished on the 2nd day of the 9th month. ${ }^{38}$

The justification for this translation project was premised more on faith in European medicine than on evidence of efficacy. Based on Western sources,

34. Yamamoto 1982: 19-23.

35. Fujikawa 1972: 498-513.

36. Shingū 1859: n. p.

37. Shingū 1858, vol. 1: 41 .

38. Shingū 1858, vol. 1: foreword 1-2. 
several contemporary Japanese writers noted that cholera had first spread from the Indian subcontinent from 1817 and during the 1830s reached to Europe and North America for the first time. ${ }^{39}$ Hence Europeans had more experience with the disease than did the Japanese. In the face of a new epidemic, Shingū and his collaborator threw themselves into this project, as he later recounted:

The two of us devoted our efforts to translating this work in the face of this rapidly spreading epidemic. We closely read the chapter on prevention and obtained various medicines, including calumba root. In this way we were able to create an alcoholic decoction [with red wine and calumba root] as a preventive medicine, which we and our families drank; we also gave it to our acquaintances... [We took] 50 drops three times daily, added to one cup of good sake before meals. The theory was that the calumba should prevent the rotting of bile and strengthen the stomach. Other [ingredients] were to strengthen the stomach. The wine and alcohol were to help expel the corrupted $k i[j a k i]$ in the body. Many people were helped in this way. ${ }^{40}$

Later in this same work, Shingū wrote that he had treated 42 cholera patients and had cured 33-a high success rate when considering that 50 to 60 percent of cholera patients often die if left untreated. His main treatment seems to have been a combination of salt water, sugar water, and rice water. It seems likely that this was based on treatments for kakuran, since there was no Western therapy in Japan at the time that used this combination. Because these are the basic ingredients for oral rehydration therapy, the main treatment for the disease today, there is good reason for this high recovery rate. Despite his success, this treatment did not become widespread and Shingū himself advocated Most's recommended treatment: calumba root and red wine. Although calumba did not become a staple of the Japanese pharmacopeia at this time numerous texts on cholera published during subsequent decades did call for wine and sometimes brandy. All of these substances would have been extremely expensive and difficult to procure. Shingū also recommended opium to treat cholera. This also would have been expensive and difficult to acquire, yet perhaps easier to find than red wine was at the time. The emphasis on alcohol and opium as treatments, and at least for the former as a preventive measure, continued throughout the century even as explanations of cholera's pathology and etiology changed considerably.

Shingū's approach and analytical methods reflected current trends. Although he kept case records, he did not systematically compare treatment

39. Umetani 1858: 3; Shingū 1858: vol. 1, foreword 1; Umasugi 1859: n. p.

40. Shingū 1859: n. p. 
methods numerically. In addition, even when translating (from Dutch) a text by a German physician, he explained the efficacy of alcohol as a preventative based on the familiar notion of corrupted life force energy $(\mathrm{ki})$; this parallels similar conceptual cross-overs that occurred in China around the same time. ${ }^{41}$ In this way, the importation of ideas occurred on the basis of existing conceptions of pathology and physiology.

\section{Changing views of endemicity: 1877-1900}

The Japanese experience with cholera points to the limits of the imaginary of pandemics as spreading worldwide. The first wave of cholera definitely fit in the first pandemic, which is usually dated from 1817 to 1824 . The second and third pandemics, dated from 1827 to 1835 and from 1839 to 1856 , did not reach Japan. Four of the subsequent cholera epidemics in Japan, in 1858, 1862, 1877 , and 1879, did not occur during global pandemics: the fourth pandemic is dated from 1863 to 1875 . On the other hand, subsequent Japanese epidemics during the 1880s and 1890s did occur during the fifth pandemic, which went from 1881 to 1896. In any event, from 1877 until 1924, cholera cases if not fatalities appear annually in government statistics, marking the beginning of endemic cholera that occasionally developed into domestic epidemics if not regional or global pandemics. Japan's largest single epidemic, in 1879, caused over 100,000 deaths with a case fatality rate of 65 percent; this year also fell between the standard pandemic dates. Between 1877 and 1900, cholera deaths reached five figures on five separate occasions, with a total of over 360,000 deaths during those years (see Table 1). Indeed, cholera cases were reported every year between 1877 and 1924, and became rare only after $1930 .{ }^{42}$

41. Andrews 1997: 122-129.

42. "Patients and Deaths of Infectious Diseases and Food Poisoning (1876-1899)." 


\begin{tabular}{|c|c|c|c|c|}
\hline & Cases & Deaths & Case fatality rate $(\%)$ & $\begin{array}{l}\text { Works on Cholera in NDL } \\
\text { Digital Data Base }\end{array}$ \\
\hline 1876 & 0 & 0 & - & 0 \\
\hline 1877 & 13,816 & 8,027 & 58 & 18 \\
\hline 1878 & 902 & 275 & 30 & 0 \\
\hline 1879 & 162,637 & 105,786 & 65 & 10 \\
\hline 1880 & 1,580 & 618 & 39 & 24 \\
\hline 1881 & 9,389 & 6,237 & 66 & 1 \\
\hline 1882 & 51,631 & 33,784 & 65 & 9 \\
\hline 1883 & 969 & 434 & 45 & 6 \\
\hline 1884 & 904 & 417 & 46 & 1 \\
\hline 1885 & 13,824 & 9,348 & 68 & 0 \\
\hline 1886 & 155,923 & 109,012 & 70 & 7 \\
\hline 1887 & 1,228 & 655 & 53 & 12 \\
\hline 1888 & 811 & 460 & 57 & 4 \\
\hline 1889 & 751 & 431 & 57 & 1 \\
\hline 1890 & 46,019 & 35,422 & 77 & 3 \\
\hline 1891 & 11,142 & 7,767 & 70 & 2 \\
\hline 1892 & 874 & 497 & 57 & 4 \\
\hline 1893 & 633 & 364 & 58 & 16 \\
\hline 1894 & 546 & 314 & 58 & 1 \\
\hline 1895 & \begin{tabular}{|l|}
55,144 \\
\end{tabular} & 40,241 & 73 & 8 \\
\hline 1896 & 1,481 & 908 & 61 & 10 \\
\hline 1897 & \begin{tabular}{|l|}
894 \\
\end{tabular} & 488 & 55 & 0 \\
\hline 1898 & 655 & 374 & 57 & 1 \\
\hline 1899 & \begin{tabular}{|l|l|}
829 \\
\end{tabular} & 2 & 0 & 0 \\
\hline 1900 & \begin{tabular}{|l}
378 \\
\end{tabular} & 0 & - & 1 \\
\hline
\end{tabular}

"NDL" is the Japanese National Diet Library

Table 1. Cases, Deaths, and Case Fatality Rate, 1877-1900

As one would expect, the epidemic of 1877 drew a great deal of attention from the medical community, as did subsequent major epidemics, with substantial numbers of monographs on cholera usually being printed in the year following a major outbreak (see Table 1). The National Diet Library lists two books published on cholera in 1871 and 18 in 1877, but none in the intervening years. Nor does it record any as having been published in 1878, but 10 were published in 1879 and 24 in 1880 . The year 1893, when 16 works on cholera were printed, was an exception to this trend. However 12 of the books published that year were the Home Ministry Hygiene Bureau's (Naimushō Eiseikyoku) accounts of the epidemics of $1877,1879,1882,1885,1886$, and 
1890. The Kumamoto prefectural government also published in 1893 a record of the epidemic of 1891. While all of these works include short historical depictions of cholera in Japan until that date, they focus on how the epidemic unfolded in each prefecture. The most detailed of all the reports is for the epidemic that occurred in 1879, which included descriptions of how people in each prefecture resisted the Hygiene Bureau's cholera control measures. It is not clear why all of these works were published in 1893. The report for the epidemic of 1877 , for example, is dated as having been written in November of that year. ${ }^{43}$ One possibility is that they were originally written for internal use by the Hygiene Bureau which later decided to make them public.

Of particular interest here are inconsistencies they contained from year to year in how observers understood cholera's origins. In the report of the epidemic in 1877, Nagayo Sensai, who was the founding head of the Hygiene Bureau and remained in that position until 1892, wrote:

In the past, when cholera has appeared and become epidemic in Japan, it was sufficient to say that in all cases it had arrived from Java or from China. However in specific locales there are now spontaneous cases of one or several cases of cholera or even small epidemics of cholera. In this respect it has become a kind of local disease $[f \bar{u} d o b y \bar{o}]$, and even today it has not completely disappeared although I believe that it will eventually be eliminated. ${ }^{44}$

National statistics for cholera morbidity and mortality were not compiled and published until the previous year, so it is somewhat puzzling that Nagayo would have made such a blanket statement. It is, moreover, telling that he considered cholera-which was still a relative newcomer-to be a localized, and in that sense endemic, disease described by the term füdobyō. Nagayo shared a popular view of cholera described in Hata Ginkei's Chimata no yume (Streetcorner dreams). This was a collection of essays for general readers on the cholera epidemic of 1858 , which in at least one scenario described cholera as caused by demons specific to a particular locale, who could be scared away by using Buddhist amulets. ${ }^{45}$ Indeed, there was a great deal of popular belief that cholera, like other diseases such as smallpox, had local deities as their cause. In addition to the above work by Hata, Kanagaki Robun's Ansei korori ryūko $k i$ provides examples of beliefs that deities caused cholera. ${ }^{46}$ In other

43. Naimushō Eiseikyoku 1893 [1877]: 5.

44. Naimushō Eiseikyoku 1893 [1877]: 4.

45. Hata 1858: n. p.

46. Kanagaki 1858: 19b-20a; 24a. 
words Nagayo, while by no means associating himself with popular religious beliefs, was not particularly unusual in claiming that cholera had become a local disease.

Subsequent annual outbreaks confirmed endemicity although there was resistance to admitting it. The epidemic that started in March of 1879 and became the largest on record originated in Ehime Prefecture; it spread from there to Oita Prefecture and then across the rest of Japan. Seemingly reluctant to admit that the epidemic had domestic origins, authors of the Home Ministry's report on that epidemic claimed that Chinese sailors had first brought cholera to Nagasaki but cited no evidence and no explanation as to how Chinese sailors in Nagasaki might have instigated an outbreak in Ehime. ${ }^{47}$ The epidemic that started in 1882 clearly originated in Kanagawa. Yet this was ambiguous, in that simply by citing Kanagawa - where the port of Yokohama and numerous foreigners were located - as the starting point might have been sufficient at the time to imply a foreign origin, although the authors of that year's report make no such claim. ${ }^{48}$

On the other hand, the official report of the relatively minor epidemic of 1885 depicted all previous cholera outbreaks as having been brought to Nagasaki or Yokohama from other parts of Asia, that year from China. ${ }^{49}$ The narrative thread of that year's cholera epidemic created an implied hierarchy between China and Japan. As the origin of the disease, China was placed in the position of an inferior nation, whereas Japan was described as a civilized, modern nation on the cutting edge of science. The Hygiene Bureau sent the bacteriologist Kitasato Shibasaburō to Nagasaki to confirm the presence of the "comma bacillus," which had been confirmed in 1883 as the cause of cholera by Kitasato's future mentor, Robert Koch. ${ }^{50}$ Nagayo's contention eight years earlier that cholera had become endemic ran against this somewhat triumphalist narrative, and as a consequence was ignored, although Nagayo himself remained head of the Hygiene Bureau at this time.

Yet the following year's epidemic, the second worst on record, put to rest the idea that outbreaks of cholera had to be of foreign origin. The epidemic was reported as having multiple sources, all domestic. In early January of 1886, cholera appeared in Osaka, without any reported links to foreign sources. At the time, Osaka was a city of canals from which people drew drinking

47. Naimushō Eiseikyoku 1893 [1879]: 1.

48. Naimushō Eiseikyoku 1893 [1882]: 1.

49. Naimushō Eiseikyoku 1893 [1882]: 3, 5.

50. Naimushō Eiseikyoku 1893 [1882]: 4. 
and cooking water, at the same time dumping sewage into them. ${ }^{51}$ Later that January, cholera also struck fishermen in Tokushima Prefecture, starting a localized outbreak that lasted for approximately two months. And in March of that year, another localized outbreak appeared in Wakayama Prefecture, also lasting for several weeks. Cholera then spread throughout most of the country, with only distant parts of Kyushu and Hokkaido being spared with a small number of cases.

Although the epidemic of 1886 was the result of endemic cholera, this fact did not bring attention to the hundreds of deaths from the disease that occurred in "non epidemic" years or permanently change understandings of its epidemics as being primarily of foreign origin. In reality, by the 1860s, Japan had become entwined in a network of microbial transmission that ignored political boundaries in East Asia. Cholera had become regionally endemic and epidemics could have had either local or more distant origins. The next major epidemic, in 1890, did seem to have foreign origins, although the evidence is circumstantial.

In June of 1890, cholera struck the resident of a village in Nagasaki Prefecture who had helped unload a German ship that had just arrived from Hong Kong. Other dock workers from another village had previously died from a severe diarrhea, although they had been buried before it was confirmed as cholera. The official report of that year's epidemic argued that the harbors and ports of Nagasaki were constantly unloading ships from China and India, and as a consequence were subject to cholera outbreaks. ${ }^{52}$ While this certainly was possible, it is telling of contemporary understandings regarding cholera and Japan's relation to the disease that official government reports insisted on its foreign origins. It seems probable that as the Japanese adopted Western institutional forms and technologies more quickly than their neighbors in Korea and China, they became loath to see a disease associated with filth as endemic to their own country. Public health officials had reason to believe that their progress with public health measures implied that cholera epidemics had to be of foreign origin. The official report on the epidemic of 1890 discussed at length how cholera prevention had become the responsibility of the police, with local municipalities directly enforcing the central government's laws on cholera prevention and disinfection. It went on to claim that despite some initial problems with the implementation of this system, the results went "beyond expectations." 53

51. Naimushō Eiseikyoku 1893 [1886]: foreword, p. 2, main text, p. 1.

52. Naimushō Eiseikyoku 1893 [1890]: 1-2.

53. Naimushō Eiseikyoku 1893 [1886]: foreword, p. 3. 
This view might have predominated had the epidemic of 1895 not occurred. With over 50,000 reported cases and 40,000 deaths, that year's epidemic was the third worst on record. Happening as it did in the midst of Japan's first modern war, it also instigated significant reforms. Nagayo Sensai wrote that cholera was a threat to the state and that it had to be prevented from entering Japan from abroad, in particular via mail boats from the continent. He also demanded that people stop hiding cases and that they think of going to quarantine hospitals as a necessary sacrifice for the state, and by implication no different from that of soldiers who were sacrificing themselves at war. ${ }^{54}$ Perhaps in response to Nagayo's call for more stringent measures, although he had left the Hygiene Bureau in 1891, the government instituted further reforms following this epidemic. Where previously the local police had been left in charge of prevention and disinfection measures, from 1895 the Tokyo Metropolitan Police Department (Keishichō) was put in charge of national cholera control with the establishment of the Office of Cholera Prevention (Korera Yobō Jimusho), which also was given responsibility for controlling dysentery and plague.$^{55}$ One reason for this was the fact that military personnel coming from China had brought the disease into Japan via Hiroshima and Moji in Fukuoka. Another reason was the expectation that the strict leadership of the Tokyo Metropolitan Police Department could implement not only the Cholera Prevention and Disinfection Law but also the "Cleanliness Law" (Seiketsu Hō) and related measures, which required the regular cleaning of houses, separation of wells and latrines, and similar measures. ${ }^{56}$ In the long run, these changes seem to have been successful in that national cholera epidemics ceased after 1895 . Only on two more occasions did reported cases of cholera exceed 10,000, when they reached 13,362 in 1902 and 10,371 in 1916.

To observers today, it might be surprising that the Japanese people had to be instructed and encouraged regarding cleanliness. Yet before this top-down enforcement of sanitary measures, it was primarily members of the samurai class and the economic elite who regularly cleaned their residences. The official reports on cholera note that people did not separate latrines and water sources and that in some parts of the country open cesspools were common. In this way, understandings of cholera that associated the disease with filth and making these understandings the basis for government policy did more than anything else both to control the disease and to change habits regarding personal and public hygiene. It is notable that unlike in Germany, as discussed

54. Nagayo Sensai, Dai Nippon Shiritsu Eisei Kai zasshi: 646, 653-654.

55. Keishichō 1896: 1,3.

56. Keishichō 1896: 1. 
below, the rise of bacteriological thought was not necessary as a justification for the central government's intervention in local communities and individual households alike.

\section{The bacteriological shift}

Some readers probably have noted that bacteriology has been almost entirely absent from this discussion of changing epistemologies of cholera in Japan. In no small part this is because while important, it played a secondary role in how people other than medical and public health specialists understood the disease. As noted in the official record concerning the epidemic of 1885, Japanese health officials certainly were aware of Robert Koch's having established the "comma bacillus" as the cause of cholera, although debates concerning its exact etiological role continued in Japan and Europe alike for another decade. However the discovery of the cholera bacillus in itself changed virtually nothing with regard to the prevention and control of the disease. It seemed to affirm the validity of disinfection measures using primarily carbolic acid, as well as calls for people to boil their water and avoid contaminated foods, measures that had been advocated from the 1870s ${ }^{57}$ And knowledge of the cholera bacillus did nothing for therapy, as contemporary observers noted. ${ }^{58}$ Physicians continued to struggle in their attempts to find effective therapeutic measures and emphasized the use of opiates well into the twentieth century.

Discussions of the cholera's etiology in the Japanese medical community followed lines of intellectual identity and allegiance. In response to the first two epidemics in 1822 and 1858, that identity depended on whether one thought of disease in terms of Chinese or Western medicine. As growing numbers of Japanese medical students went to Europe - primarily Germany in the nineteenth century, ideas of etiology depended more upon the views of one's European teachers. With the emphasis on German schools, however, the bacteriological thought of Louis Pasteur or the hygienic ideas of John Snow received little attention in the Japanese medical world. For the most part, those who had studied with Robert Koch accepted his bacteriological theory and those who had studied with Max von Pettenkofer supported his multi-factorial theory of cholera's etiology. There was little doubt to either that cholera was somehow transmitted from person to person, but the mode of transmission remained an object of debate until the last decade of the nineteenth century.

57. Nomura 1877: 4; Uratani 1877: 2.

58. Maeshima 1886: 850 . 
Hence quarantine and disinfection, measures that had been implemented by the 1870 s, remained the cornerstone of cholera control.

Ishiguro Tadanori, in his synthesis of several German texts on cholera that he published in 1871, supported Pettenkofer's thesis that something in the feces of cholera patients transmitted the disease, while also asserting that it could be spread through the air. ${ }^{59}$ However it was during and following the epidemics of 1877 and 1879 that cholera became firmly associated with some kind of organism, which led to an emphasis on control through quarantine and disinfection. The numerous texts that advocate disinfection, however, do not generally theorize its efficacy. Following Pettenkofer and others, some writers speculated that a microscopic organism was responsible for the disease and by implication that disinfection neutralized those organisms; at least one work published an illustration, presumably drawn from an unnamed German text to which it refers, that showed microscopic "plants" thought to cause cholera. ${ }^{60}$

As a consequence, although the Japanese medical community was aware of Koch's confirmation that the "comma bacillus" caused cholera, not all of its members saw the discovery as particularly momentous. ${ }^{61}$ As noted above, Kitasato Shibasaburō was sent to Nagasaki in 1885 to determine whether the bacillus caused the disease. He reaffirmed Koch's bacteriological theory but doing so made no significant difference to prevention or therapy. During the rest of the 1880s and into the early 1890s, the primary debate among Japanese physicians regarding the etiology of cholera was between supporters of Koch's theory that the bacillus alone caused the disease and supporters of Pettenkofer's theory that emphasized soil and ground water as key elements in causing the disease. ${ }^{62}$ The difference between the two theories with regard to cholera control policies was significant. Koch's focus on the bacillus called for an emphasis on disinfection, quarantine, and keeping human waste out of water supplies. Politically, Koch's position called for government intervention to reach these goals. Pettenkofer's position represented an extension of earlier miasmatist thought and called for a broad, social hygiene approach to the control of disease. He advocated minimal government intervention and emphasized the local control of poor sanitary conditions that had been associated with the outbreak of an epidemic, conditions based on a combination of meteorological, geological, and statistical analyses. ${ }^{63}$ Pettenkofer's theories were eventually

59. Ishiguro 1871: 5-6.

60. Itō 1879: n. p.

61. "Doitsu koku korera byō kenkyū iin no hōkoku" 1884: 773-774.

62. Tsuboi 1893: 78-80.

63. Evans 1987: 269-271, 494-496. 
eclipsed after 1892, when a cholera epidemic devastated Hamburg, whose leaders had championed his ideas for controlling the disease. Nevertheless, some writers in Japan continued to question the idea that water-borne bacilli were the main cause of cholera as late as 1893 , while others continued to support Pettenkofer's theory the following year. ${ }^{64}$ After 1894, however, Pettenkofer's ideas regarding cholera received little attention in the Japanese medical press. Rather it is telling that in 1895, we find Nagayo Sensai calling for municipal supervision of cholera prevention measures, focusing on quarantine hospitals and disinfection, the same measures that had provided the focus for cholera control for nearly two decades. However where Nagayo had declared that cholera was a local disease in 1877, in 1898 we find an anonymous writer in the leading public health journal, Dai Nihon Shiritsu Eisei Kai zasshi, asserting that it was the "opening" of Japan that made the country susceptible to the disease and that it always was and remained a foreign threat. ${ }^{65}$ Although in reality a relatively new microorganism had occupied the country during the last third of the century, as time went on, the Japanese increasingly understood it as something extrinsic.

In addition, it is important to note that despite the emphasis by historians of medicine in recent years on John Snow's ideas concerning the role of water in the transmission of cholera, the Japanese medical press hardly mentioned Snow throughout the nineteenth century. ${ }^{66}$ Although the idea that water transmitted the disease persisted in Japanese understandings of cholera, until the very end of the century the means for dealing with impure water fell on the individual, through disinfection or boiling. It was not until the very end of the century that we find the literature on public health calling for the municipal control of water sources as the best way to prevent cholera, dysentery, and other water-borne diseases. ${ }^{67}$ Until then, ideas of hygiene based on individual behavior, even if it was forms of behavior that followed the direction of the central government, dominated understandings of cholera and its control. Thus, the rise of bacteriology did not radically transform Japanese control policies regarding cholera. Rather it reinforced claims that the involvement of the central government was necessary to enforce behavioral changes in historically unprecedented ways while often emphasizing the individual in ways that did parallel the ideas of $y \bar{o} j \bar{o}$.

64. Yasuhara 1893: 254, 271; Watanabe 1894: 46-56.

65. "Densenbyō no shinro" 1898: 373-376.

66. Vinten-Johansen et al. 2003; Johnson 2006; Hempel 2007.

67. Noda 1899: 425-449. 


\section{Conclusion}

The ways in which Japanese physicians and health officials saw and understood cholera as it swept across the country in epidemic waves and eventually became endemic reflect the broad changes that the country experienced during the nineteenth century. One set of changes marked Japan's increasing integration in a global network of pathogenic exchange, and can be divided into three periods: the first included the first two epidemics of 1822 and 1858; the second reached from the late 1870s to approximately 1890; the third spanned last decade of the century.

Foreign contact first brought the disease well before the "opening" of Japan in 1853. The second epidemic in 1858 clearly entered via Nagasaki, and as a consequence could have happened the way it did even before the treaty ports other than Nagasaki were made accessible to foreigners. Yet as the collections of popular essays on cholera by Hata Ginkei and Kanagaki Robun reveal, at least to many people in Japan cholera was not yet understood so much as a foreign threat as a result of demonic or karmic influences; that is, an existential threat whose origins were less important than the challenge of survival. This perspective contrasts starkly with the Kyoto physician Shingū Ryōkaku's work, which is based largely on a text on cholera by the German physician Georg Friedrich Most and describes the disease as originating in India and coming to Japan.

Whether there were any significant cholera epidemics during the 1860 s is debated. Contemporary Western observers did report the disease in 1862, but Yamamoto Shun'ichi, author of the most comprehensive history of cholera in Japan, questions whether the epidemic that struck was actually cholera ${ }^{68}$ In any event, by the time the next major epidemic struck in 1877 , the disease had become so pervasive that Nagayo Sensai considered it to have become a local disease $(f \bar{u} d o b y \bar{o})$, in other words endemic to certain parts of the country. This was, in all likelihood, an accurate observation. Our knowledge of Vibrio cholerae as it stands today strongly suggests that the organism that causes cholera could have become acclimated to Japanese waterways and estuaries by this time. And the statistical record, which shows that there were at least hundreds and often thousands of cases of the disease every year between 1877 and 1900, also strongly suggests that cholera had indeed become endemic in Japan - that in effect Vibrio cholerae had occupied the country-during the last third of the nineteenth century. Nevertheless, understandings of cholera during that time, while becoming increasingly influenced by German debates

68. Simmons 1880: 4; Yamamoto 1982: 26; New York Times 1862: 2. 
over etiology, claimed the opposite and described the disease as a foreign intruder. Most likely this is the result of many in Japan seeing their country as leading Asia's move toward modernization, which was associated with health and hygiene; cholera, on the other hand, had obvious associations with filth, debilitation, and death. There was, in short, a narrative based on ideas of civilization that depicted other Asian countries, and in particular China, as inferior that created the structure for late nineteenth century narratives regarding cholera in Japan. Japanese accounts of the disease tended to describe cholera as coming from China, and with the Sino-Japanese War of 1894-1895, China also became the great obstacle to Japan's paternalistic and imperialistic efforts to facilitate the modernization of continental Asia and of Korea in particular.

What we see in the history of cholera in nineteenth century Japan is a case of disease associated with identity, and the epistemological framework for the disease was transformed, not just in the sense of its laboratory understandings but also in the sense of where the disease fit in a new cultural and political order. These understandings, more than those of emerging laboratory science and bacteriology, were the ones that dominated the public health discourse of the day. The historical process that they represent is a shift, a translation of a cluster of concepts that constitute understandings of cholera from ones that shifted individual responsibility for the disease from the ideas of $y \bar{o} j \bar{o}$, karma, and demonic spirits to the ideas of disinfection, isolation, and sanitation. The process did require growing state intervention, but even this required local cooperation and support. The drift that occurred was not simply a top-down process. Yet when the epistemology of the disease is considered in this wider context, it becomes clear that the way in which ontological shifts based on bacteriology and laboratory science more broadly played only a supporting role in this historical process. Historical continuity remains, even as the ontology of the disease is unstable. While this case is itself relatively minor when considered on a world stage, when one considers that all epidemics are local events, it has lessons that can be useful when trying to understand how they occurred in other localities. 


\section{BibliograPHY}

ANDOH Yoshinori 安東由則 (2003). “Shintai kanri to 'kokumin’ keisei: kindai gakkō e no 'eisei' no dōnyū o megutte” 身体管理と「国民」形成一近代学校への 「衛生」の導入をめぐつて一 (Management of the body and the formation of "citizens": issues surrounding the introduction of "hygiene" in modern schools). Mukogawa Joshidai kiyō (Jinbun, Shakaigaku) 武庫川女子大紀要（人文 社 会), vol. 51: 99-109.

Andrews Bridie (1997). "Tuberculosis and the Assimilation of Germ Theory in China." History of Medicine and Allied Sciences, vol. 52: 114-157.

Bunsei jingo aki tenkō byō koreri morubusu keiken 文政王午秋天行病可列刺莫児蒲 期経験 (Experiences with cholera morbus during the epidemic of 1858). Handcopied manuscript, not dated, Fujikawa Bunko, Kyoto University Library.

Chemouilli Philippe (2004a). "Le choléra et la naissance de la santé publique dans le Japon de Meiji 1. Modernité, choléra et pensée hygiénique." M/S: médecine sciences, vol. 20, no. 1: 109-114.

Chemouilli Philippe (2004b). "Le choléra et la naissance de la santé publique dans le Japon de Meiji 2. Forces et faiblesses d'une politique de santé publique." $M / S$ : médecine sciences, vol. 20, no. 2: 236-240.

Chemouilli Philippe (2004c). "Les épidémies de choléra et la mise en place d'un système d'hygiène moderne." Cipango, no. 11: 173-208.

Colwell Rita (1996). "Global Climate and Infectious Disease: The Cholera Paradigm." Science, New Series, vol. 274, no. 5295: 2025-2031.

Colwell Rita (2004). "Infectious Disease and Environment: Cholera as a Paradigm for Waterborne Disease.” International Microbiology, vol. 7, no. 4: 285-289.

“Densenbyō no shinro” 伝染病の進路 (The routes of infectious diseases) (1898). Dai Nippon Shiritsu Eisei Kai zasshi 大日本私立衛生会雑誌, no. 182: 373-376.

“Doitsu koku korera byō kenkyū iin no hōkoku” 独逸国虎列剌病研究委員の報告 (Report of the German research group on cholera) (1884). Tokyo iji shinshi 東京 医事新誌, no. 325: 773-774.

Elman Benjamin (2008). "Sinophiles and Sinophobes in Tokugawa Japan: Politics, Classicism, and Medicine During the Eighteenth Century." East Asian Science, Technology and Society, vol. 2: 93-121.

Evans Richard (1987). Death in Hamburg: Society and Politics in the Cholera Years, 1830-1910. Oxford: Oxford University Press.

Faruque Shah M. and Mekalanos John J. (2012). "Phage-bacterial Interactions I the Evolution of Toxigenic Vibrio cholerae." Virulence, vol. 3: 1-10.

FUJIKAWA Yū 富士川游 (1972). Nihon igaku shi 日本医学史 (A history of Japanese medicine). Tokyo, Keiseisha.

GibBons Ann (2013). “The Thousand-Year Graveyard.” Science, vol. 342: 1306-1310.

Gramlich-OKa Bettina (2009). "The Body Epidemic: Japan's Cholera Epidemic of 1858 in Popular Discourse.” EASTM, vol. 30: 32-73. 
Hata Ginkei 畑銀鶏 (1858). Chimata no yume 街廼夢 (Street-corner dreams). 3 vols. Edo, Gotokudō.

Hempel Sandra (2007). The Strange Case of the Broad Street Pump: John Snow and the Mystery of Cholera. Berkeley, University of California Press.

HIRAHARA Yūteki 平原有的 (1842). Korera ben 国漉栗辨 (A treatise on cholera). Hand-copied manuscript, Fujikawa Bunko, Kyoto University Library.

IsHIGURo Tadanori 石黒忠惪 (1871). Korera ron 虎烈刺論 (Cholera studies). Tokyo, Daigaku Tōkō.

ITō Motoshi 伊東本支 (1879). Korera yobō minkan no kokoroe 虎列剌予防民間の心 得 (Popular essentials for the prevention of cholera). Tokyo, Tōkōsha.

Johnson Steven (2006). The Ghost Map: The Story of London's Most Terrifying Epidemic-and How It Changed Science, Cities, and the Modern World. New York, Riverhead Books.

Johnston William (2012). "Epidemics Past and Science Present: An Approach to Cholera in Nineteenth-Century Japan." Harvard Asia Quarterly, vol. 14, no. 4: 28-35.

KANAGAKI Robun 仮名垣魯文 (1858). Ansei korori ryūkō ki 安政箇労痢流行記 (A record of the Ansei-era cholera epidemic). Edo, Tenjudō.

KEISHICHŌ 警視庁 (1896). Korera byō ryūkō kiji Meiji 28 虎列剌病流行紀事明治 28 年 (A record of the cholera epidemic of Meiji 28 [1895]). Tokyo, Keishichō.

Latour Bruno (1988). The Pasteurization of France. Cambridge (Mass.), Harvard University Press.

Latour Bruno (2005). Reassembling the Social: An Introduction to Actor-NetworkTheory. Oxford, Oxford University Press.

LegGe James (repr. 1971). Confucius: Confucian Analects, The Great Learning, and The Doctrine of the Mean [1893]. New York, Dover.

MacPherson Kerrie L. (1998). "Cholera in China, 1820-1930: An Aspect of the Internationalization of Infectious Disease." Elvin, Mark and Liu Ts'ui-jung, Sediments of Time: Environment and Society in Chinese History. Cambridge, Cambridge University Press: 487-519.

MAESHIMA Nagahiro 前嶋長裕 (1886). “Korera sōdan” 虎列剌叢談 (Discussions on cholera). Tokyo iji shinshi 東京医事新誌, no. 430: 850-852.

Mатsumoto Jun 松本順 (1980). Ranchū jiden 蘭疇自伝 (The autobiography of Matsumoto Jun). Ogawa, Teizō and Sakai Shizu, Matsumoto Jun jiden · Nagayo Sensei jiden 松本順自伝 . 長与専斎自伝 (The autobiographies of Matsumoto Jun and Nagayo Sensai). Tokyo, Heibonsha.

MATsuURA Kyūkō 松浦久功 (1859). Chōshi itsū wake 張氏医通和解 (A study of Master Zhang's medical practice). Hand-copied manuscript, Fujikawa Bunko, Kyoto University Library.

NAGAYO Sensai 長与専斎 (1895). “Korera yobō ni tsuite” 虎列剌予防に就て (On the prevention of cholera). Dai Nippon Shiritsu Eisei Kai zasshi 大日本私立衛生会 雑誌, no. 146: 645-658. 
NAIMUSHŌ EISEIKYOKU 内務省衛生局 (1893). Korera byō ryūkō kiji Meiji 10 虎列剌 病流行紀事明治 10 年 (A record of the cholera epidemic of Meiji 10 [1877]). Tokyo, Naimushō Eiseikyoku.

NAIMUSHŌ EISEIKYOKU 内務省衛生局 (1893). Korera byō ryūkō kiji Meiji 12 虎列剌 病流行紀事明治 12 年 (A record of the cholera epidemic of Meiji 12 [1879]). Tokyo, Naimushō Eiseikyoku.

NAIMUSHŌ EISEIKYOKU 内務省衛生局 (1893). Korera byō ryūkō kiji Meiji 15 虎列剌 病流行紀事明治 15 年 (A record of the cholera epidemic of Meiji 15 [1882]). Tokyo, Naimushō Eiseikyoku.

NAIMUSHŌ EISEIKYOKU 内務省衛生局 (1893). Korera byō ryūkō kiji Meiji 19 虎列剌 病流行紀事明治 19 年 (A record of the cholera epidemic of Meiji 19 [1886]). Tokyo, Naimushō Eiseikyoku.

NAIMUSHŌ EISEIKYOKU 内務省衛生局 (1893). Korera byō ryūkō kiji Meiji 23 虎列剌 病流行紀事明治23 年 (A record of the cholera epidemic of Meiji 23 [1890]). Tokyo, Naimushō Eiseikyoku.

NAKAJIMA Yōichirō 中島陽一郎 (1982). Byōki Nihon shi 病気日本史 (A history of disease in Japan). Tokyo, Yūzankaku.

New YoRk Times (14 December 1862). "Interesting from Japan": 2.

NoDA Tadahiro 野田忠廣 (1899). “Mizu to eisei” 水と衛生 (Water and hygiene). Dai Nippon Shiritsu Eisei Kai zasshi 大日本私立衛生会雑誌, no. 193: 425-449.

Nomura Chōsaburō 野村長三郎 (ed.) (1877). Korera byō hōkoku sho 虎列剌病報告 書 (A report on cholera). Tokyo, Kanzawasha.

ODAI Yōdō 尾台榕堂 (1864). Kakuran chiryaku 霍乱治略 (The treatment of kakuran [mordisheen]). Edo, Gyokusandō.

"Patients and Deaths of Infectious Diseases and Food Poisoning (1876-1999)." Accessed September 12, 2012: www.stat.go.jp/english/data/chouki/24.htm.

SASAKI Chūtaku 佐々木中沢 (n.d.). Jingo tenkō byōsetsu 王午天行病説 (A study of the [epidemic] disease of 1858). Hand-copied manuscript. Waseda University Library.

SAYES Edwin (2013). "Actor-Network-Theory and Methodology: Just What Does It Mean to Say that Nonhumans Have Agency?" Social Studies of Science published online December 30, 2013, accessed January 9, 2014.

SHINGŌ Ryōkaku 新宮凉閣 (1858). Korera byō ron コレラ病論 (Studies on cholera). 2 vols. Kyoto, Neijūdō.

SHINGO Ryōkaku 新宮凉閣 (1859). Korori kiji コロリ記事 (A record of the cholera). Hand-copied manuscript. Fujikawa Bunko, Kyoto University Library.

Simmons Duane B. (1880). Cholera Epidemics in Japan: With a Monograph on the Influence of the Habits and Customs of Races on the Prevalence of Cholera. Shanghai, Statistical Department of the Directorate General of Customs.

TAKI Mototsugu 多紀元胤 (repr. 1918) Honzo kômoku hōchū vol. 1 本草綱目:補註上 巻 (An annotated materia medica) [1590]. Tokyo, Handaya Shuppanbu.

Takizawa Toshiyuki (2011). "Asian Ideas on Health Promotion and Education from Historical Perspectives of the Theory of Yojo as an Interface of Health, Self, and Society.” In Muto Takashi, Toshitaka Nakahara, and Eun Woo Nam (eds.), Asian 
Perspectives and Evidence on Health Promotion and Education. Tokyo, Springer: 3-12.

Tsubor Jirō 坪井次郎 (1893). “Pettenkoferu shi saishin korera setsu” ペッテンコー フエル氏最新虎列剌説 (Dr. Pettenkofer's latest theory of cholera). Tokyo iji shinshi 東京医事新誌, no. 772: 78-80.

UMASUGI Bunrei 馬杉文禮 (1859). Shusō yawa: korera hōron 秋空夜話: 虎狼痢方論 (Discussions on an autumn evening: cholera). Kyoto, Saibikan.

UMETANi Samon 梅谷左門 (1858). Indo kakuran setsu 印度霍乱説 (A study of the Indian mordisheen). Osaka, Shōtokudō.

URATANI Yoshiharu 浦谷義春 (1877). Korera yobo kokoroe hō 格列刺予防心得法 (Cholera prevention methods). Osaka, Uratani Yoshiharu.

Vinten-Johansen Peter et al. (2003). Cholera, Chloroform, and the Science of Medicine: A Life of John Snow. Oxford, Oxford University Press.

WatAnABE Rai (trans.) 渡辺雷. “Pettenkoferu shi no korera ron” ペッテンコーフエ ル氏/虎列剌論 (Dr. Pettenkofer’s theory of cholera). Dai Nippon Shiritsu Eisei Kai zasshi 大日本私立衛生会雑誌, no. 116: 46-56.

Yамамото Shun'ichi 山本俊一 (1982). Nihon korera shi 日本コレラ史 (A history of cholera in Japan). Tokyo, Tokyo University Press.

YASUHARA Toyonari 安原豊也 (1893). “Korera byōdoku kūki yori densen no jikken" 虎列剌病毒空気より伝染の實験 (An experiment on the aerial transmission of the cholera toxin). Dai Nippon Shiritsu Eisei Kai zasshi 大日本私立衛生会雑 誌, no. 107: 253-271.

\section{GLOSSARY}

eisei 衛生

fūdobyō 風土病

furigana 振り仮名 (often written phonetically: ふりがな)

Honzo kômoku 本草綱目

jaki 邪気

kakuran 霍亂

$\mathrm{ki}$ 気

korera often this was written using katakana: コレラ. Chinese characters used were the same as those for korori; see below.

korori often this was written using katakana: コロリ; a number of Chinese characters were used phonetically for korori, including 虎狼痢, 虎烈剌, 虎列剌,古吕利,古路里, 国漉栗,箇労痢. Often these would be assigned the phonetic reading korera.

Korori ben 国漉栗辨

Korori to kokete sora ibiki コロリトコケテソライビキ (original in katakana).

Korera Yobō Jimusho 虎列剌予防事務所 


\section{William Johnston}

mikka korori 三日コロリ (While this was often written using the phonetic katakana, korori could also be written using any of the Chinese characters for korori that are noted above)

mikka tonkoro 三日トンコロ

reiki 厲気

Seiketsu Hō 清潔法

Shōkanron 傷寒論

yōjō 養生

Yomego no hirune mo korori to se ヨメゴノヒルネモコロリトセ (original in katakana).

Zhang Zhongjing 張仲景 